\title{
Minding Bodies: Demons, Masks, Archetypes, and the Limits of Culture
}

\section{John Emigh}

The standard social science models-especially as taken up by the humanities - have had trouble allowing both for cross-cultural communication and for diversity and individual agency within culturally defined regions. Peggy Phelan once remarked that performance "exists as a negotiation between biology and culture." As a theatre director and teacher by training and trade with research interests in Asia and Latin America, I have found that attention to some of the concerns and findings of cognitive neuroscience can provide a reality check on the rhetoric of the emergent field of performance studies, with its vital links to anthropology and cultural studies.

What is the role and what are the limits of "culture" in neural processing? And how are these germane to performance? Gerald Edelman has shown how central categorical constructions are to the workings of our ever-shifting neural networks; surely, the relative strength of taboos and the strength of binaries used in categorical construction vary from place to place and time to time. ${ }^{2}$ Bradd Shore has argued for a reassessment of the ways in which "cultural models" embodied in cognitive patterns encourage "a significant overlap [among individuals] within a community as to how novel experiences will be reconstituted as memory," with nurture becoming nature. ${ }^{3}$ Granting this as a possibility, I propose to tease out some of the limitations and functions of cultural constructs while considering a phenomenon that seems to transcend culture: the "archetype" of the demonic face and its mirror opposite, the apotropaic (protective) face, as encountered in masks and mask-like images around the world.

In place after place and time after time, masks and sculpted faces have been deployed that feature bulging eyes, full lips, flared nostrils, bared fangs, and, frequently, distended tongues. The Gorgoneion of Greece, Rangda and Bhoma of Bali, Kirtimukha of South and Southeast Asia, Shakti figures of India, enraged

\footnotetext{
John Emigh is professor emeritus of theatre arts and performance studies at Brown University. He was founding chairperson of the Association for Asian Performance, is the author of Masked Performance (University of Pennsylvania Press, 1996) and of other writings on South and Southeast Asian performance, and in 1996 was principal consultant for the Indira Gandhi National Centre for the Arts' exhibit Masks, Mind, and Man in New Delhi (CD forthcoming). He has directed over seventyfive plays and performed one-person shows based on Balinese masked dance and theatre. In 2009, he received the Association for Theatre in Higher Education's Career Achievement Award for Educational Theatre.
} 
Boddhisatvas of Tibet, certain Iroquois False Faces of North America, the fierce generals of the Anshun Earth Opera of China, the auspicious Shi-shi Mai of Japan and festival dragons of China, the jaguars and goddesses of old Mexico/new Spain, the Xue Xue of the Northwest Coast Kwakiutl, and variants of the Devil and Witch found throughout Europe and the Americas all fit this description (see figs. 1 and 2). There are, of course, other masks in these locales, and routes of transmission can be speculated about and have sometimes been determined. Still, this approach to incorporating certain images into masks is not only broadly distributed, it frequently reappears after periods of absence. What, then, accounts for the appeal and staying power of these images? Why do they occur and reoccur with such frequency? And in such various contexts!

The masks tend to be quite large and, when worn, are out of proportion with the trunk of the body as perceived by the visual system. They often blend human traits with those of powerful beasts of prey: lion, tiger, bear, or jaguar. Sometimes the references are more fanciful: the dragon, the chimera, and the Warner Brothers' "Tasmanian Devil" (see figs. 3, 4, and 5). Studies of visual tracking indicate that the eye focuses obsessively on the mouth, nose, and eyes to "read" a human face, perhaps to glean the

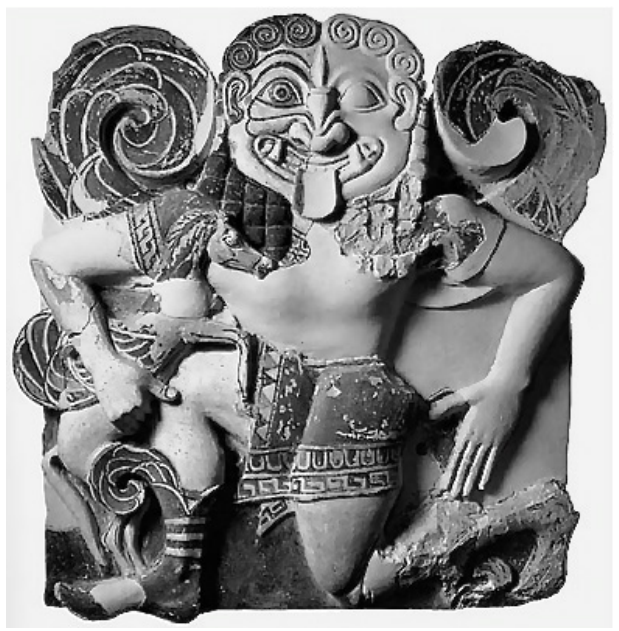

Fig. 1. Terracotta Gorgon Relief, Archaic Greece, 625600 BCE (Courtesy Museo Archeologico Regionale Paolo Orsi, Siracusa, Sicily, Italy)

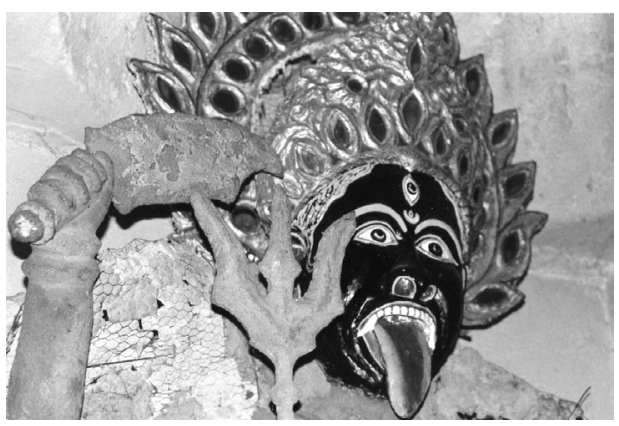

Fig. 2. Mask of Kali on an unfinished statue, Andhra Pradesh, India (@ John Emigh)

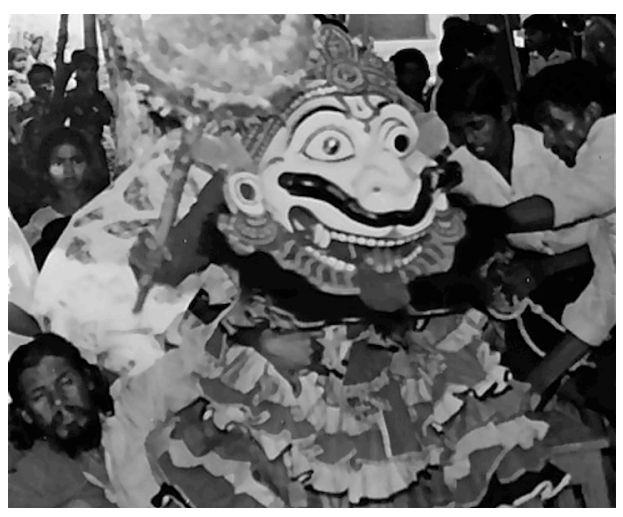

Fig. 3. Vishnu's man-lion avatar, Narasimha, in a Prahlada Nataka performance, Ganjam, Orissa, India (C) John Emigh) 
disposition of the other. ${ }^{4}$ These masks and mask-like images almost always exaggerate such features through a process of simplification and amplification related to the "peak shift" phenomenon that V. S. Ramachandran associates with artistic process. ${ }^{5}$ Yet their expressions, while often suggesting ferocity, do not correspond (as other masks frequently do) to any of the recognizable sets of characteristics that have been identified with displays of "primary" human emotions as identified by Ekman and his associates: the eyes are too enlarged and the mouth pulled back too far for anger; the nostrils are too flared for fear; the characteristic distended tongue matches neither anger nor fear; and sometimes a trace of mirth seems present. ${ }^{6}$ Art historian David Napier suggests that the arresting presence of leonine apotropaic faces found on shields in ancient Greece and the Kirtimukha figures that adorn temple gateways and feature prominently in exorcistic performances of South and Southeast Asia can, in part, be traced precisely to this ambiguity of emotional affect (see figs. 6 and 7). ${ }^{7}$

While they do not seem to depict any stable human emotion, Oohashi Tsutomu points out that these masks do bear a striking resemblance to the "threat display" as identified

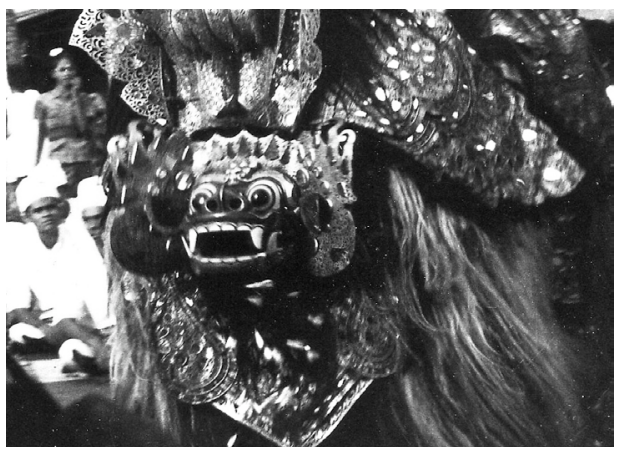

Fig. 4. Barong Ket in a Calonarang performance, Bali, Indonesia (C) John Emigh)

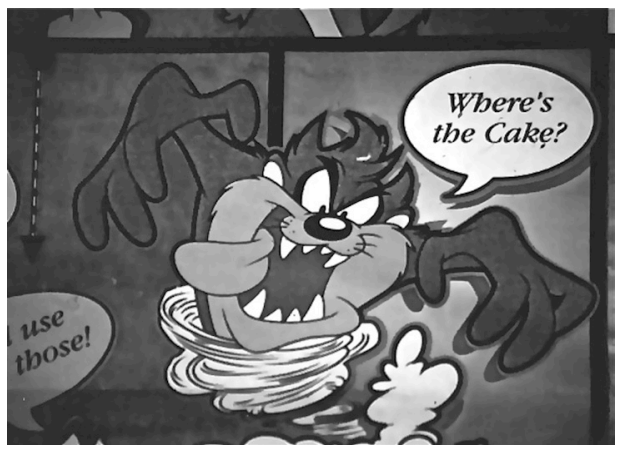

Fig. 5. The Warner Brothers' Looney Tunes character, "Taz" The Tasmanian Devil, pictured on gift-wrapping paper (Courtesy Warner Brothers Entertainment, Inc.)

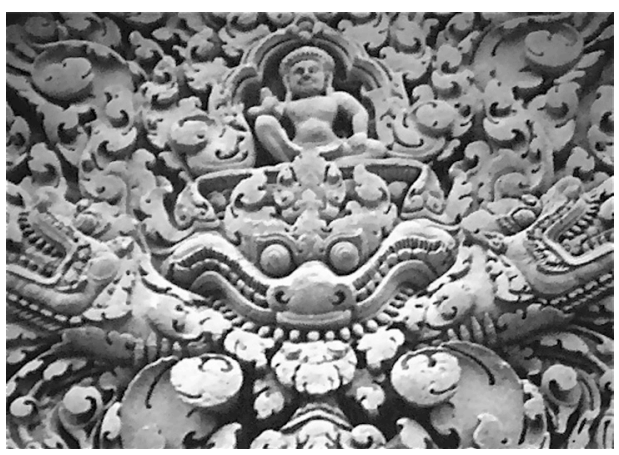

Fig. 6. Decorative Lintel with Kirtimukha figure and Shiva, Angkor Thom, Cambodia, Twelfth Century CE (C) John Emigh)

by ethologists: the transitory expression made in response to danger - all senses alert, caught between fear and fury - that serves as a warning and may precede a ferocious attack, or, for that matter, a grudging retreat. ${ }^{8}$ One striking transposition of this threat display onto the human face is in the Maori warrior or All Blacks 
rugby player's fearsome grimace, made with the eyes bulged out and tongue protruded (see figs. 8 and 9).

While the mimicry of threat displays-especially those of powerful predators-may well account for some of the widespread appeal these figures have (or at least their power to arrest attention) as well as the mixed feelings that they engender, Napier briefly proposes another possibility. ${ }^{9}$ Apotropaic figures characteristically exaggerate all the instruments for gaining sensory information: eyes, ears, nostrils, tongue, and fingers are commonly rendered larger than "natural." Not only are all of Rangda's sensory organs exaggerated in her oversized face, but her fingers, too, are extended by the use of gloves with grotesque nails of buffalo horn; and this extension of the fingers is not unique to Rangda (see fig. 10). The same technique is sometimes deployed, for example, in the costuming of Inuit shamans. Whatever else they may convey, the images of Rangda, the Kirtimukha, and many similar images distributed across the globe, may well draw their power and appeal from a particular resonance

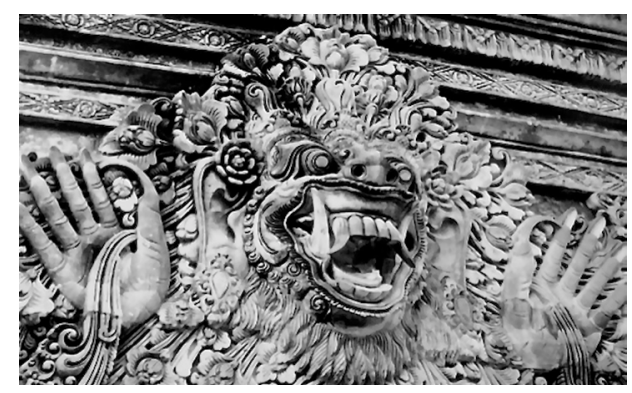

Fig. 7. Bhoma's face and hands on the lintel of a temple gate, Bali, Indonesia (C John Emigh)

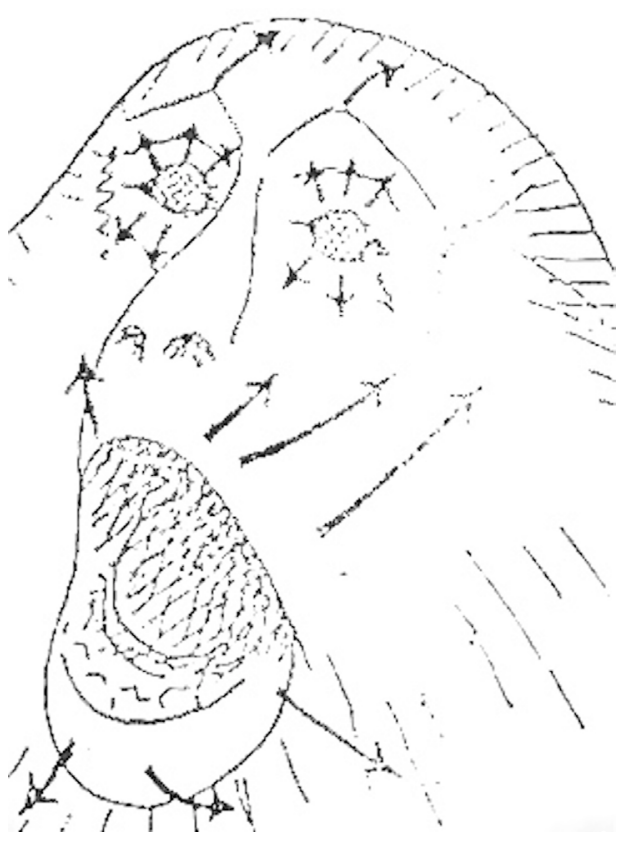

Fig. 8. Drawing showing the changes in musculature during the threat display of an ape (Courtesy Oohashi Tsutomu). with the human brain's monitoring of bodily sensation.

Through signals arising from touch and movement, the rest of the body is continually monitored by the brain. Antonio Damasio has suggested a simple demonstration of this constant monitoring and argues for its primacy in establishing an initial basis for selfhood. ${ }^{10}$ The demonstration entails first looking right and left without moving the head; then making the same motion while being conscious of the movement of the eyes within the sockets. This is easily done, and the point is that these feedback sensations are always present but usually do not arrest conscious attention. 
As has been long established, though, this monitoring of the body is not done democratically. Graphic reconstructions of the proportionate neuronal representation accorded parts of the body within the somatosensory area of the brain's neocortex yield a "homunculus" with a tiny body and huge face, hands, and tongue (see fig. 11).

The various images of the "homunculus" found in textbooks ultimately derive from the seminal studies of Wilder Penfield and T. Rasmussen, first published in 1950, which mapped the proportionate dedication of neurons to various body parts in topographic representations within the brain. ${ }^{11}$ At least ten different somatotopic representations of the body have now been detected, each with discrete sets of neurons involved in monitoring different modalities of sensory information-movement, pressure, temperature, pain-in both the right and left hemispheres. ${ }^{12}$ While there are some variations, these somatotopic representations are quite similar. The image most frequently shown specifically represents the area in the neocortex that monitors and mediates motion in the right hemisphere of the brain - the same hemisphere that is most strongly associated with affective response, metaphoric thought, and artistic activity. The graphic representation of this "homunculus" was more vivid than

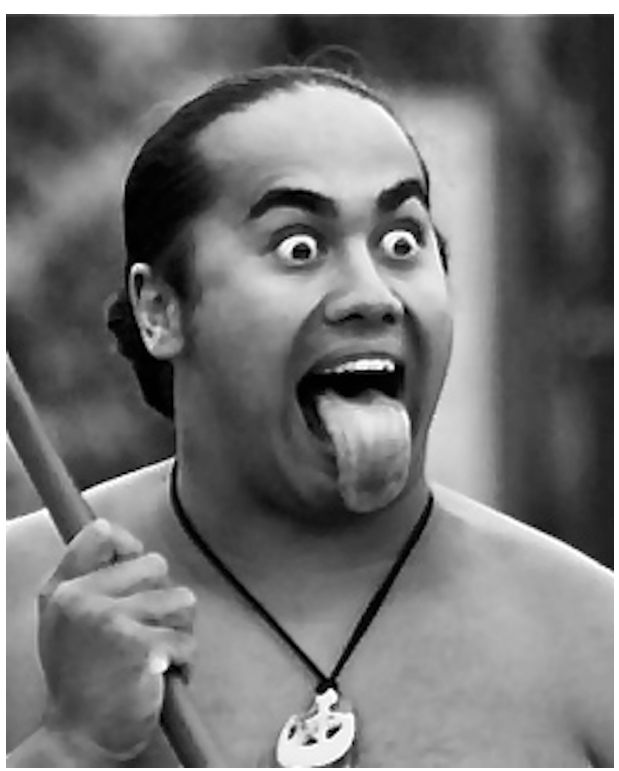

Fig. 9. Maori Kapa Haka, the moment of pukana, Rotorua, New Zealand-Aotearoa (Adapted from a photo by Jasja van Leeuwen and used courtesy of the photographer)

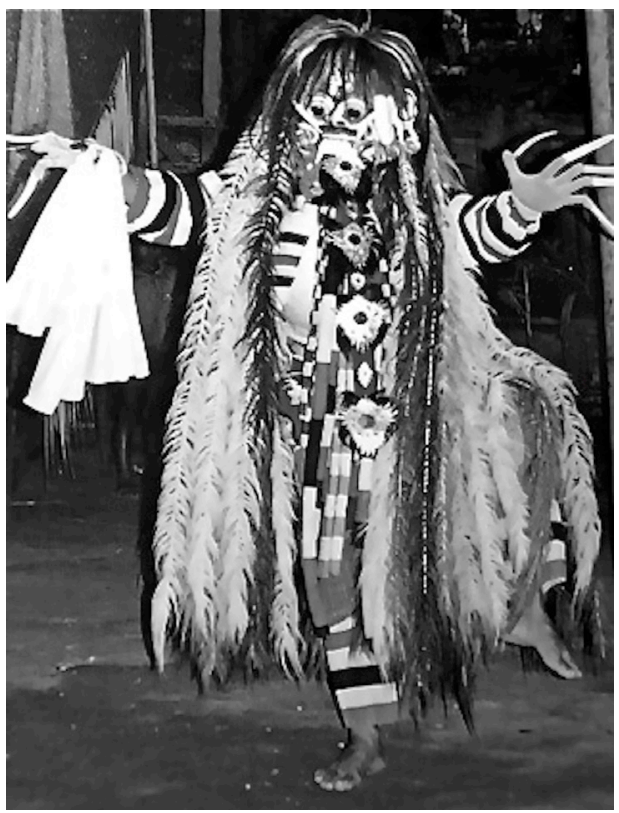

Fig. 10. Rangda in performance, Bali, Indonesia (C) John Emigh) the one constructed for the adjacent somatosensory cortex itself, though very similar 
to it in its proportions. It also has the advantage of being more unisexual, and (likely for both of these reasons) is often substituted for that of the somatosensory homunculus. This accounts for the puzzling lack of representation for genitalia (see fig. 12). ${ }^{13}$ Universalists, beware!

The complexly gendered Rangda and her many cousins around the world all share these oddly proportioned features. ${ }^{14}$ If, as Stephen Snow (among others) has suggested, these demonic and demon-like figures have an "archetypal" appeal, then that appeal may lie not so much in the genetic transmission of universal and cultural archetypes (as Jung suggested), but in an intuitive projection of the somatosensory structures themselves as revealed, not though our visual assessment of the world, but through our constant, hierarchized monitoring of our own bodies as they move and encounter the world beyond the self. Rangda and her relatives, then, may be first and foremost images of raw, unsocialized sensation as prefigured in Damasio's "body-minded brain" (see fig. 13). ${ }^{15}$

The somatosensory cortex sends the information received out to the posterior parietal cortex, where integration with other sensory information - including information from the visual system takes place, and a more complete "overall picture of the body" is formed. ${ }^{16}$ It should not be surprising, then, once the importance of the sensory information gleaned through other sense organs is factored in, that the eyes, ears, and nose would be represented as much larger in apotropaic masks than in a homunculus representing the somatosensory or motor area alone. A frontal drawing following the proportions indicated and modified by the further elaboration of the features 
so important for sight, smell, and hearing would produce an image shaped very much like the Indian Kirtimukha and Balinese Rangda: all head and hands, with bulging eyes, flared nostrils, and a very prominent tongue. Perhaps significantly, this is precisely what my then five-year-old son Aaron "naively" recorded when he first encountered Rangda in 1975 (see fig. 14). ${ }^{17}$

More generally, the sensory information from the brain's monitoring of the body is also integrated with associational areas of the cortex dealing with categorical constructions and with memories that are, in turn, linked (through the limbic system) to emotional cues. These links are part of the series of reentrant loops described by Erich Harth, among others, as an optimizing system deployed in the mind's perpetual scanning of information for "meaning." " No wonder, then, that this particular representation of the body, though at considerable variance from the information given by the visual system itself, would have its own persuasiveness, and that variations might appear in cultures that seem to have had little direct contact. But no wonder, too, that the values associated with that image would be subject to wide variation, both across and within "cultures," as the body-minded brain tests out its multiple drafts of meaning and, as Harth suggests, the plastic and performing arts provide public screens for the continuation

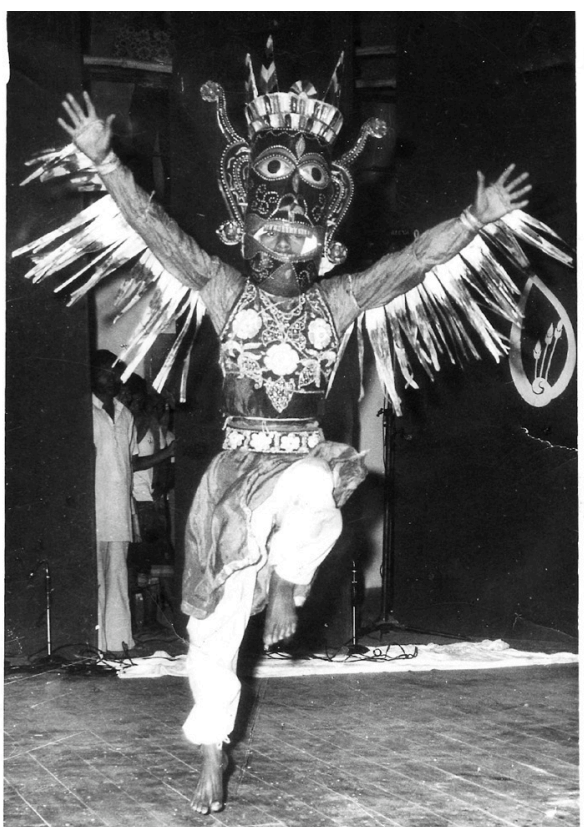

Fig. 13. Shiknidhal, a Gamira dance mask representing a dangerous local deity, Dinajpur, West Bengal, India (Courtesy Sisir Najumdar)

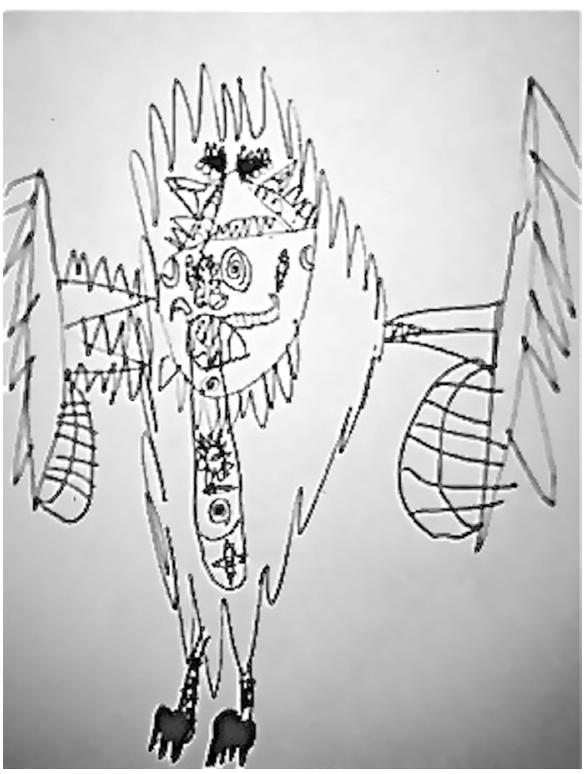

Fig. 14. Rangda as drawn by Aaron Emigh, age five, 1975 (C) John Emigh) of this private associational process. ${ }^{19}$ While there seem to be certain archetypal 
(or at least extremely widespread) attributes shared by demonic and apotropaic masks worldwide, the values - positive and negativeattached to these images vary greatly from one culture to another and from occasion to occasion and person to person within cultures.

The thoughts here were originally shared in a PowerPoint presentation as part of the conference "From the

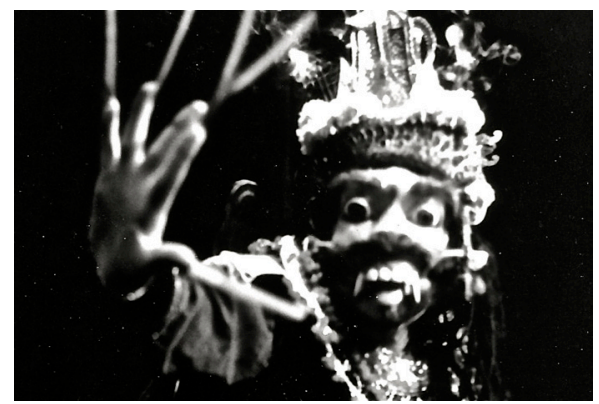

Fig. 15. Author as Dalem Bedahulu (Courtesy Ernestina Koetting) Brain to Human Culture: Intersections between the Humanities and Neuroscience" convened by John Hunter at Bucknell University in April 2007. While delivering the talk, I took the opportunity to demonstrate at this juncture the traditional performance of one such mask - that of the unfortunate Dalem Bedahulu of Bali. In the chronicles that support the masked dance-drama (Topeng) of Bali, Dalem Bedahulu (King Different-head), the last king of the Pejeng dyanasty in the fourteenth century, literally lost his head while demonstrating his superiority to the forces of life and death. A very nervous servant replaced the king's head with that of a wild boar (see fig. 15). ${ }^{20}$ The mask used in the dance-drama representing the story presents a striking amalgam of human and animal features: tongue distended, pig-like nostrils flared, and eyes opened wide. In performance, the fingers are extended with the same buffalo horn nails used for Rangda and splayed wide: the feet are wide apart and in "fourth position" with the big toes raised; the legs are open with the pelvis exposed; the dancer's energy is centered in the groin and chest areas; and snorts alternate with archaic war cries: "Irakaaaah! Warahan, Warahan!" Besides conforming well to the archetypal image being considered, Dalem Bedahulu also has his own complex narrative of strength and hubris - one central to Balinese cultural history - and this, too, would come into play in the hermeneutics of Balinese audience members, assisted by a unique shaping of the narrative by the dancer/narrator(s).

Rangda, too, is not simply an image of the body run amuck. Almost always performed by an adult male, her monstered femininity and her frequent narrative role as enraged "widow" (the literal meaning of Rangda) provides an occasion for confronting and, perhaps, containing the strains in gender politics within Balinese life. ${ }^{21}$ Wild and violent in trance, she is also (in concert with her sometime opponent, the lion-like Barong Ket), a protector of the village within the Balinese chthonian temple; and even when cast as villain, her forces are pitted against those who would practice black magic within the village. The responses that she engenders - rage, fear, devotion, affection, and even sexual attraction - are multi-faceted and paradoxical in nature. ${ }^{22}$ Different Balinese people (and the 
same people on different occasions) have very different reactions to and associations with her presence, and her "meaning" can be tinkered with, both dramaturgically and socially.

In Western iconography and performance, this internal image of the body is most frequently displayed either as the Devil or in closely related images, such as the Hellmouth from which demons appear or the Witch (see figs. 16 and 17). While the Balinese Rangda is dangerous but necessary - and ultimately beyond moral judgment-the Christian attitude toward the Devil is, at least officially, one of contempt and negation, matching an oft-expressed

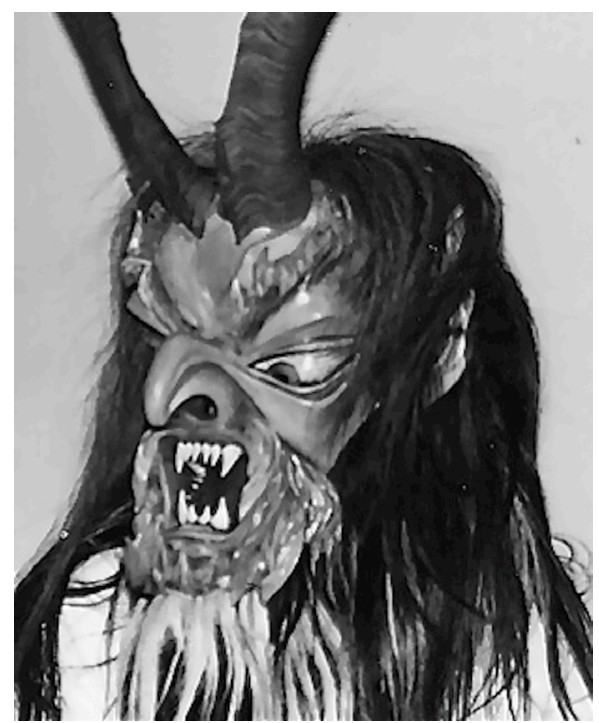

Fig. 16. Krampus (Devil) mask, Austria (C) John Emigh)

disregard for the body itself. The Greek nature god, Pan, with his cloven hooves and goat's horns, in this case, has been transformed into the grotesque and malevolent embodiment of all that is evil. But attraction to the body is not easily erased, and the devil becomes celebrated as the antihero of pre-Lenten Carnival processions: a time, fittingly, when the body is given temporary reprieve and when masks of wildmen, witches, and leering Satan himself still runs riot in some European and Latin American streets.

A fascinating Carnivalesque recuperation of the Devil, and, through his image, of the body itself, is played out in the "Días Patrias" celebration of Mexican independence in the small town of Teloloapan in Guerrero, Mexico. ${ }^{23}$ Here, as, more ambiguously, elsewhere in Mexico, devil masks have provided not only a phantasmagoric screen for all that is seemingly

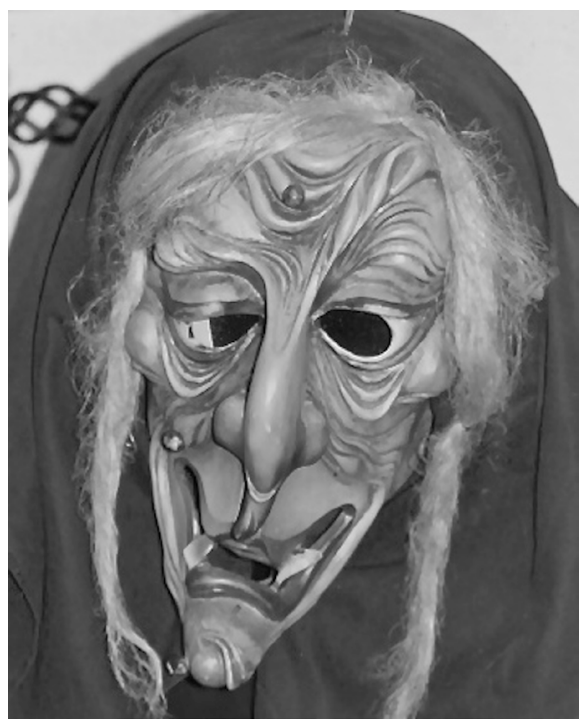

Fig. 17. Hexe (Witch) mask, Weil-der-Stadt, Baden Württenberg, Germany (C) John Emigh) antisocial, but also a vehicle for recuperating images of fertility and the abundance of nature that characterized precontact art. When the Spanish monks came into "New 
Spain," they found active performance cultures, complete with masks representing deified jaguars and aspects of nature; some of these masks may easily be regarded as variants of the "archetype" being described. These gods and their iconography were, the monks catechized, really aspects of the devil and, as such, must be scorned as the enemy of

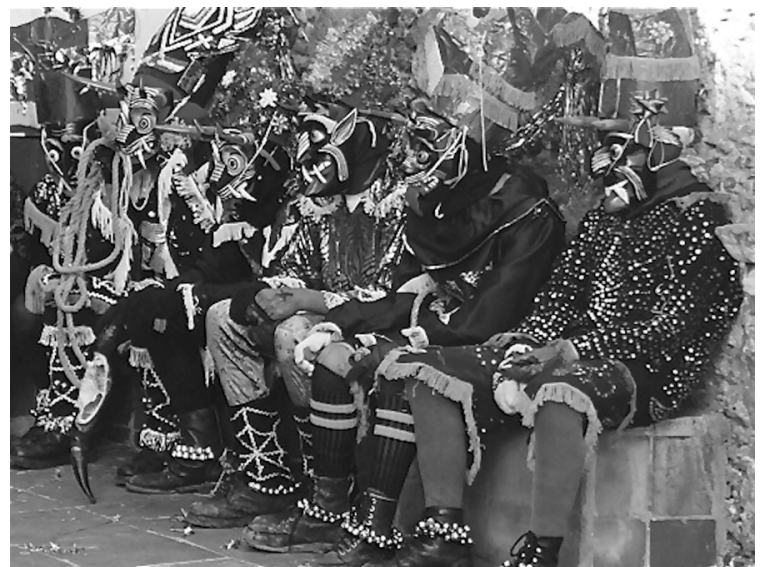

Fig. 18. Diablos resting at New Year's Day celebrations, Janitzio, Michoacan, Mexico (C) John Emigh) the true God. Morality plays were introduced, pitting the life of Christian virtue against the lure of el Diablo, and often featuring striking variants of European devil masks that folded in precontact imagery. Mesoamerican belief systems, though, did not adapt easily to such a Manichean dualism, and the devil has remained a figure of great and ambivalent fascination throughout Mexico (see fig. 18).

During the Mexican War of Independence in 1812, Vincente Guerrero and his ragtag group of revolutionaries in the rugged hill country around Teloloapan-a region also distinguished as the birth place and final resting place of Cauhtemoc, the last Aztec king-were badly outnumbered and outgunned by advancing troops from the capital of Mexico City. One of the rebel soldiers, Pedro Asencia Alquiciras, devised a plan to gather together the devil masks in the region, make more of these masks, and then don them, emerging from behind trees as an army of demons just as the loyalist troops approached. The ruse is said to have worked spectacularly, sending the pro-Spanish troops fleeing for their lives. Ever since, the mask of the devil has become a symbol of independence and patriotism in the region, and the wearing of these masks, often painted with the Mexican national colors, a regular feature of Independence Day celebrations in Teloloapan. ${ }^{24}$

As the years and a series of revolutions and their betrayals ensued, other legends accrued to these patriotic devil masks, frequently having to do with the courtship of young ladies facilitated by the masks' anonymity. ${ }^{25}$ In Teloloapan, as elsewhere in Mexico, devil masks have provided not only a phantasmagoric screen for all that is seemingly antisocial, but also a vehicle for recuperating images of fertility and the abundance of nature. It is not at all unusual in Mexican performances to see toads and snakes - traditionally positive images in Mesoamerican cultures - adorn these brightly painted devil masks. In Teloloapan, though, something else has happened. The masks have grown larger and larger (some now weigh as much as seventy-five 
pounds); multiple sheep, goat, and cattle horns have erupted from the diabolic heads; and the noses, chins and cheekbones have themselves sprouted multiple heads of jaguars, eagles, and snakes. These figures of rugged and untamed abundance are made, purchased, or rented by young men who don leather cowboy robes

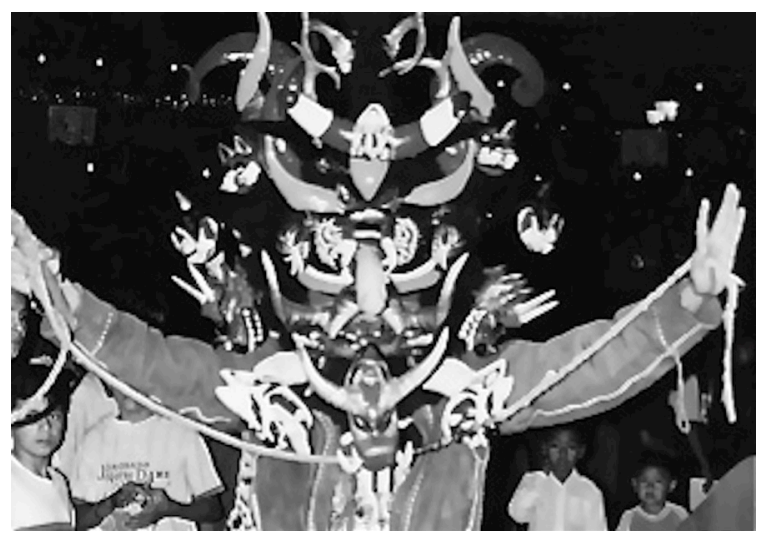

Fig. 19. A Teloloapan Diablo with his "chicote" (C John Emigh)

and walk through the street, shaking hands with small children, "capturing" willing young women, dancing with these women and with each other, and matching their skills with a whip against those who would dare challenge them (see fig. 19). In the town square (zócalo) — so important to Mexican city architecture and life - these young men, still wearing their cumbersome and colorful masks, stage contests of cowboy skills no longer necessary for the semi-urban life of the town. "What terrible devils! What heroic devils!" shouts the master of ceremonies during the presentation. They snap their long whips, or chicotes, strut and roar proudly with their phantasmagoric masks, and are judged by the festival queen and her court, proudly touted by the announcer as "representatives of the grace and beauty of Mexican culture." A sort of beauty-and-the-beast dance follows, with the queen, her court, and small girls all dancing with the devils. Still rough around the edges, the Diablos of Teloloapan have acquired culture, it seems: a cultured devil has become the very image of the ideal Guerrero male.

I have suggested that Rangda in Bali, the patriotic Diablos of Teloloapan, and their many cousins around the world owe their iconographic similarities to the shared architecture of the somatosensory system in human brains and that they are, perhaps first and foremost, images of pure, unmediated sensation. But they are also many things more, collecting and dispersing meanings in the marginal times of performance. Cultural construction still has a significant role to play in encoding and decoding these interior images of the body, re-presented in the visual field of performative play. Some of the images that share this archetypical iconography are understood to be protective and ultimately positive, others wholly negative. Some reference beasts of prey, real and imagined, others seem to be grotesques of the human face, without links to the animal world. Some are specifically "feminine," while others are "masculine" or ambiguous. Some are more comic in affect than others. Many of these differences may be ascribed to cultural constructions affecting the value and role afforded bodily sensation, the closeness of perceived links to 
other species, and the tensions around issues of gender and social status. Though the appeal of these figures may have a "universal" basis, the weightings of values in performance will vary from place to place, from time to time, and from person to person.

"Cultures" are not static entities either. Beyond their (sometimes misleading) appeal as heuristic devices, they may be productively thought of as contested terrains. In so far as they are "things" at all, "cultures" exist as shared sets of concerns, images, and categories-some of these contradictory, some more entrenched than others, and all subject to change. Ultimately, cultural constructions must exist as constellations of neuron groups in the human brains of individuals, interconnected across distributed social networks. Thus, there may be predispositions (and resistances) to relating certain images and ideas, to connecting certain categorical groupings of neurons, to using the mind by invoking similar well-exercised pathways. It may prove useful to locate the symbolic webs of culture as more or less fragile constructions within the contested consciousness of the body-minded brain. Envisioning cultural constructions in this manner may provide a way of understanding their staying power, as well as their vulnerability.

Making and viewing performances seem to be among the more productive and, potentially at least, the more pleasurable ways of giving form to these values as well as contesting their worth in a relatively safe space. The findings of neurosciencein their multiple and competing drafts - promise to provide a useful means of reminding us of the ways we are alike, as well as the ways in which, in constructing our own multiple drafts, we can be at odds: between cultures, and within our selves. Bracketing strips of behavior as performance - as somehow "re-presented" outside of the driven flow of causally chained actions and responses that constitute (or seem to constitute) everyday life - provides a way of externalizing the internal process by which disparate cues are assigned and reassigned meanings. These cues, given new significance by their selection and presentation to the view of others as percepts destined for signification, set off complex chain reactions of electrical and chemical activities dashing about axons and dendrites, catching meanings in margins and, through both predictable and unpredictable bisociative connections, enforcing and breaking apart categorical constructions, looping back into memory, provoking bursts of laughter or fleeting moments of comprehension, and, ultimately, changing the ways in which we can view the world and the configuration of the neurons that must make sense of the viewing.

There is some evidence, on display at conferences such as those recently held at Bucknell and the University of Pittsburgh and in a growing body of literature, that our modest but growing comprehension of how the brain works will span the sciences and humanities, helping to break down the now outdated trope of "two cultures," antithetically opposed. Perhaps it will also serve to reshape the trope (or "meme") of culture itself, while we agree to disagree — with each other, with 
ourselves, with the past, and with those others who essentially share our mental architecture. Performances serve to project the mind's sketching and paradigm-making abilities out beyond the confines of the individual being, where other minds can assess the persuasiveness and power of our fleeting, embodied visions: affirming and denying, remembering and forgetting, assimilating them into old categories, forging new ones, blending fantasy and reality in fragile images

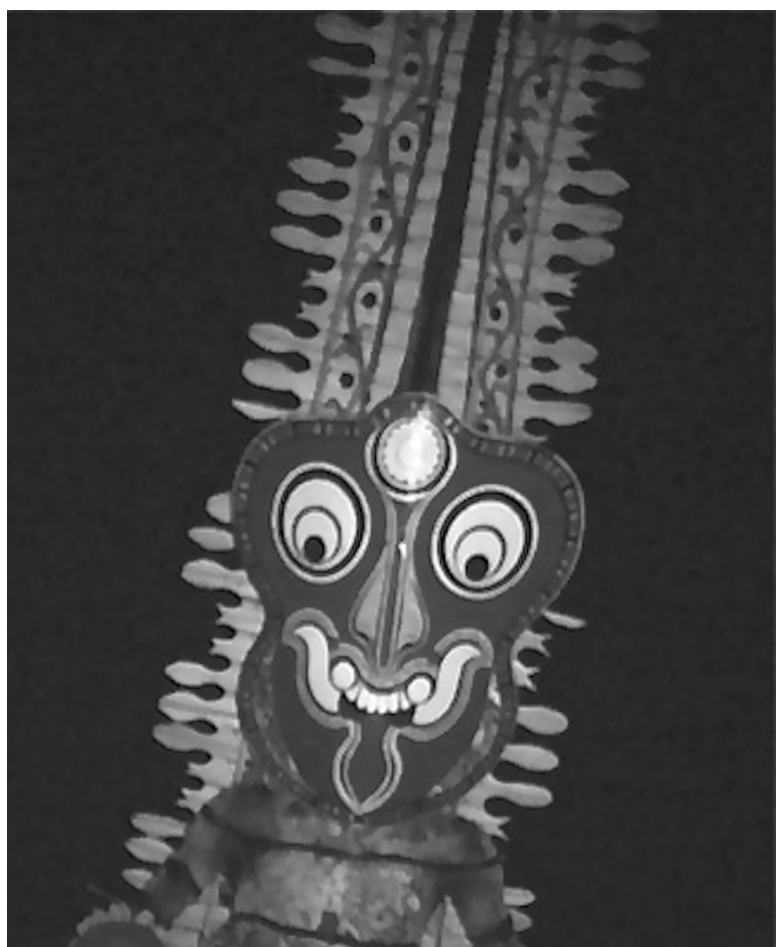

Fig. 20. Teyyam mask, Kerala, India (C) John Emigh) inspired by our biological selves, reassigning neurons, shifting storage areas, strengthening weak synaptic connections and making new ones, rededicating neurons used to store information that has fallen into disuse, and maybe, if we are very lucky, using this process as a way to live better, or at least to enjoy the passage of our time here more fully (see fig. 20).

\section{Notes}

1. Phelan's remark was made in the course of a performance studies international conference, at Georgia Tech University in Atlanta, 1997, where I first presented some of this material. The present essay is based on PowerPoint presentations delivered at the conferences convened by John Hunter ("From the Brain to Human Culture: Intersections between the Humanities and Neuroscience" at Bucknell University, April 20-21, 2007) and Bruce McConachie ("Symposium on Theatre and Cognitive Studies," University of Pittsburgh, February 27-28, 2009).

2. Gerald M. Edelman, Bright Air, Brilliant Fire: On the Matter of the Mind (New York: Basic, 1992); Gerald M. Edelman, Wider Than the Sky: The Phenomenal Gift of Consciousness, (New Haven: Yale UP, 2004); Gerald M. Edelman and Giulio Tononi, A Universe of Consciousness: How Matter Becomes Imagination (New York: Basic, 2000).

3. Bradd Shore, Culture in Mind: Cognition, Culture, and the Problem of Meaning (New York: Oxford UP, 1996) 372.

4. David Norton and Lawrence Stark, "Eye Movements and Visual Perception," Scientific American 224.6 (1971): 34-43.

5. V. S. Ramachandran, A Brief Tour of Human Consciousness: From Imposter Poodles to Purple 
Numbers (New York: Pi, 2004).

6. Paul Ekman, V. Wallace, and Phoebe Ellsworth, Emotion in the Human Face (New York: Pergamon, 1972); Paul Ekman, Emotions Revealed: Recognizing Faces and Feelings to Improve Communication and Emotional Life (New York: Times, 2003).

7. David A. Napier, Masks, Transformation, and Paradox (Berkeley: U of California P, 1986) 209. For more on the Kirtimukha tradition and how my thoughts in this essay relate to Napier's observations, see John Emigh, Masked Performance: The Play of Self and Other in Ritual and Theatre (Philadelphia: U of Pennsylvania P, 1996) 35-41, 60-74.

8. Oohashi Tsutomu, "Shishi and Barong: A Humanbiological Approach on Trance-Inducing Animal Masks in Asia," Masked Performances in Asia: International Symposium on the Conservation and Restoration of Cultural Property (Tokyo: National Research Institute of Cultural Properties, 1987) 136-38.

9. Napier, Masks, Transformation, and Paradox 205

10. Antonio R. Damasio, Descartes'Error: Emotion, Reason, and the Human Brain (New York: Putnam's Sons, 1994) 223-35.

11. Wilder Penfield and T. Rasmussen, The Cerebral Cortex of Man: A Clinical Study of Localization and Function (New York: Macmillan, 1950). For representations of the "homunculus" in neuroscience textbooks see, e.g., Eric R. Kandel, James H. Schwartz, and Thomas M. Jessell, Principles of Neural Science, $3^{\text {rd }}$ Edition (Norwalk, CT: Appleton, 1991) 370-74, 610-11, and 707; Mark F. Bear, Barry Connors, and Michael Paradiso, Neuroscience: Exploring the Brain, $3^{\text {rd }}$ Edition (New York: Lippincott, 2006) 413-15, 474-75; and Semir Zeki, A Vision of the Brain (Oxford: Blackwell Scientific, 1993) 148-51.

12. Kandel et al., Principles 367-83.

13. See, for example, Kandel et al., Principles 707.

14. For an account of Rangda's complex play with gender see John Emigh and Jamer Hunt, "Gender Bending in Balinese Performance," Gender in Performance: The Presentation of Difference in the Performing Arts, ed. Laurence Senelick (Hanover, NH: UP of New England, 1992) 195-222.

15. Stephen Snow, "Rangda: Archetype in Action in Balinese Dance Theatre," Themes in Drama, Vol. 5: Drama and Religion (London: Cambridge UP, 1986) 273-91; Damasio, Descartes' Error 70, 155-60, 223-44.

16. Kandel et al., Principles 383.

17. It is worth noting that Aaron's picture is also characterized by the sort of zigzag "entoptic" patterns that David Lewis-Williams and David Pearce, in Inside the Neolithic Mind: Consciousness, Cosmos and the Realm of the Gods (London: Thames \& Hudson, 2005), have associated with the depiction of altered states of consciousness. Frequently (though certainly not always) the masks under discussion are used as vessels for trance possession. Oohashi ("Shishi and Barong" 128-53) draws particular attention to these connections between mask and trance. While there is no room to explore such associations in this essay, the reader is referred to Margaret Coldiron's Trance And Transformation Of The Actor In Japanese Noh And Balinese Masked Dance-Drama (New York: Edwin Mellen, 2004) and my forward to her book. While there is a great deal that remains of mystery, a promising line of enquiry has been advanced by Eugene D'Aquili and Andrew Newberg in The Mystical Mind: Probing the Biology of Mystical Experience (Minneapolis: Fortress, 1999) and by Newberg, D'Aquili and Vince Rouse in Why God Won't Go Away: Brain Science and the Biology of Belief (New York: Ballantine, 2001). Following their line of reasoning, one of the attributes that would distinguish such a trance possession is the separation of the right orientation area that facilitates the body's movements from any sense of a personal, historical self in control of movement and memory.

18. Erich Harth, The Creative Loop: How the Brain Makes a Mind (Reading, MA: Addison Wesley, 1993). See also Douglas Hofstadter, I Am a Strange Loop (New York: Basic, 2007).

19. Harth, The Creative Loop 75-76. The metaphor of "multiple drafts" is taken from Daniel Dennett, Consciousness Explained (Boston: Little, 1991). For a more lengthy treatment of this process as it relates to making and experiencing of performance, see John Emigh, "Performance Studies, Neuroscience, and the Limits of Culture," Teaching Performance Studies, ed. Nathan Stucky and Cynthia Wimmer (Carbondale: Southern Illinois UP, 2002) 261-76.

20. The story has many variants. For one account, see Beryl de Zoete and Walter Spies, Dance and Drama in Bali (Kuala Lumpur: Oxford UP, 1973 [1938]) 295-96.

21. See Emigh and Hunt, "Gender Bending" 207-17.

22. See Fred B. Eisman, Jr., Bali: Sekala and Niskala, Vol. I: Essays on Religion, Ritual, and Art (Berkeley: Periplus, 1989) 315-21.

23. Research in Teloloapan was conducted with Ulrike Emigh and Anne Johnson in 1992 and 1995-96. I am indebted to the citizens and mask makers of that town, and especially to Daniel Soriel 
Roldón Aquilar and Fidel de la Fuente Fabián, for their generous cooperation. Other Mexican mask makers who supplied related information used above are Baldomero Mendoza of Chapa, Guerrero, and Juan Horta Castillo, and Victoriano Salgado Morales of Michoacan.

24. Francisco Nájera Cartrejón, Leyenda Costumbrista Vol. 3: Los Diablos de Teloloapan (Teloloapan, Guerrero: General Jesús H. Salgado Museo Municipal, n.d.).

25. Victor Olea, Teloloapan a Traves de los Tiempos (Teloloapan, Guerrero: Círculo Social y Cultural Telolopanse, A.C., 1987). 
